It is certain that the disease in question is very seldom rapidly fatal, and perhaps experience does not afford a single unequivocal exmmple of its ever having been so. At the same time, when fatal, it unquestionably is 80 in the way of syncope, and there is nothing inconsistent with experience in conceiving that such a disease may have existed in General Dick, and that for a considerable time, in a latent form, and that it may have been secretly or insen-ibly undermining his little remaining vis vita, and then, that this haring reached a certain point, the system, or the heart's action, at last, somewhat suddenly and unexpectedly, but not unaccountubly or mysteriously, gave way.

And if that disease existed and operated as the cause of death, we need not concern ourselves as the jury, frow the terms of their verdict, seem to have done, to enquire into the cause of the disense; if only we are satistied that it was not produced by poison. Every event in nature indeed must have à allequate cause; but disease, in a thousand different cascs, originntes from inappreciable causes; and it would be quite sufficient in regard to the case before us, to say that the disease originated spontaneonsly, or was produced by " natural causes."

But while I admit thit gastro-eneritis may have eristed, and been the cause of denth in this case, and while I ain sutisfied that the facts of the cuse do not warrant the belief, nor even the suspicion of poisoning, there is another view of the case to which I an disposed to attach considerable importance.

Might not the death have occurred independently of any actual diserse, and been owing to a cause trivial in itself, but deriving its efficacy from his advanced age, and leaving no trace of its agency behind it in the dead body? And might not this cause have been the excitement attendant on entertaining his fiends the evening previous to his death; or some unobserved circumstance connected with that entertuinment? The records of medicine abound in cases of sudden death occurring in individu.ts who were, to all appenrances, the moment hefore in perfect health; in whom, on examination after death, all the orgains exhibited the character of health. In some such cases, also, it has been impossible, ufter the most careful inquiry, to discover the ngency of my external canse to which the death could reasonably be ascribed ; in others of them, however, it has been possible, with wore or less contidence, to refer it to strong mental emotion, to peculiar sensations, or to excessive muscular exertion. (See Review on 'Travers's work on " Constitutional Irithtion," in Edinburyh Medical and Surgical Journal, vol, xxvi. pp. 325, 6., aná Allison's Puthulogy, p. 13.)

Now, I would sub:nit, that in forming an opinion on any such case as the present, we ought never to overlook the consideration that death may have been produced exclusively, or in part, by oue or other of the causes just specitied; or lhat it may have occurred independently of any actual disease, or any exfernal violence- "spontaneously" in short; a considerution which is well calculated to relieve our minds of the misgivings which might otherwise spring up in them.

To bring these remarks to a point, I am of opinion that the facts of the case as recorded in your "Observations," do not admit of a positive conclusion as to the cause of death. We can say indeed, that it is not improbable that gastro-enteritis existed in a lateur form, and it may have been the cause of death; but it is nearly equally probable that the death occurred independently of any such disease, from circumstances connected with the advanced age of the General, and which left no trace' of their agency in the dead body. Negatively, however, we can affirm with the utmost confidence, that the recorded facts do not warrant the helief or even the suspicion of poison laving been given, or of death having occurred otherwise than "naturally." And as it regards the objects of truth and justice, this conclusion, negative as it is, is abundantly satisfactory. Those objects do not require that the cause of death should be clearly and unequivo. cally made out. It is sufficient if it can be established that the deceased came by his death naturally, or if it cannot be shown that he came by it violently; and of this, (latter ulternative,) there is not only no proof, but nothing, (in the medical facts,) to render it probable.

The verdict of the jury is an unhappy one; to sxy the least, it is ambiguous, and does not dispose of the question, to determine which the inquest was held. They might, with great propriety, I think, have returned a verdict of "Died by the visitation of God."

The very lucid and logical reasoning contained in Dr. Harvey's letter, cannot, I am assured, fail to interest many members of the Association; and I shall not apologize for again attempting to fix the attention of the profession on a case, the discussion of which, both in private circles and in the pages of an influential medical journal, has developed so unch of uncertaintyand contrariety of opinion on such important subjects as the latency of inflammation in vital organs, - the impossibility of determining the cause of death from the symptoms and the appearances on dissection, - and the possibility of senile death withont any ascertainable exciting cause or any discernible disense. The peculiar circumstances of the present case are more especially interesting to the connections of the deceased; the instifution of the inquest, and the medicul doctrines that have been set forth on the case, are of surpassing interest to the medical profession and to society at large.

$$
\begin{gathered}
\text { I am, Sir, } \\
\text { Yours faithfully, } \\
\text { EDWARD BLACKMORE. } \\
\text { Bath, October 1, } 1845 .
\end{gathered}
$$

\section{CASE OF PLACENTA PRAEIA.}

By J. Hutchinson, Esq., Cheethain Hill, near Manchester.

On Monday afternoon last, about three o'clock, I ivas sent for to Mrs. H., aged 38, mother of eight children, who considered herself eight months advanced in pregnancy.

On my arrival, I found her very faint, baving had sudden and considerable hæmorrkage; I made a cautions examination, but finding the os uteri not much dilated, and rigid, I quietly withdrew uy finger and inserted a plug of soft linen; I remained with Ler for some time, and saw her again towards evening. She remained ensy, and free from further loss of blood until about two o'clock the following :morning, whẹn I was agiain summoned; I found her very faint, having bad 
alight pains, accompanied with trifling hæmorrhage. I proceeded to detach the placenta, which I now found to be implanted completely over the os uteri, extending about two inches on the anterior, and four or five on the posterior part of the neck of, the uterus. The pains inmedintely forced the placenta into the vagina, the membranes were ruptured, and the after-birth, which was now expelled, was separated from the cord: this was without the slightest pulsation. The child's liead presented; and as there appeared to be a disposition for labour pains, and no flooding, I waited patiently for nearly an hour, when my patient complained of fuintness, and as I found that there was a very slight discharge of serum, I now turned the child, and with some little trouble succeeded in delivering her. Matters went on well, and up to the present time she has not had a bad symptom.

At my first risit I ordered some laudanum and infusion of roses; and whilst detaching the placenta, fifty drops of Battley's sedative liquor were given, as I found the 08 uteri very unyielding. There was profuse flooding whilst I was detaching the placentu, but iamediately this was accomplished it entirely ceased, and from this time until the labour was completed, I believe not a single ounce of blood escuped; although previously at least five or six pounds must have been lost.

I have ventured to trouble you with this communication, Hs this appears to me to be a case strikingly illustrative of the good effects of the practice lately recomnended by Dr. Simpson and Dr. Radford.

Cheetham Hill, Oct. 10, 1845.

\section{PROVINCIAL \\ Atredical \& Surgical Journal. WEDNESDAY, OCTUBER 15, 1845.}

Few persons will be found in these days to ques. tion theright, or challenge the exercise, of Govern. ment protection of the insane. If the courts of law are entitled to exercise a jealous supervision over the property of minors, and individuals otherwise incompetent to manage their own concerns, still more is it requisite that a similar protective hand slionld be extended to the persons of those who, in various degrees, suffer under the loss of the brightest and most distinguishing characteristic of humanity.

The disposition of late manilested on the part of the Government and the Legislature, to divert a portion of their attention from the ambitions sehemes of foreign policy,-from the turmoils of party strife, - from the thousand and one devices for extracting a largo and fourishing public income from the resources, too often narrow and impoverished, of private iculividuals, to the far more sound and paternal schenes of legislation, which have reference to an improvement of the moral, social, and personal condition of the subjects of the State, forms a listinguishing feature of the present age. Much indeed has glieady been effected in this respect, and more is contemplated; and by the exercise of due caution and consideration in the progress of these salutary measures, so as to avoid the evils of hasty legislation, the change from almost total neglect, to a wise and liberal system of management, may be accomplished without violence or injury to any part of the community, for whose general benefit such measures are mainly intended.

The enactments already passed, or now in contemplation, for the more systematic relief of the poor, for the regulation of labour in factories and mines, for the care of the insane, for the improvement of the health of towns, for the registration of births, marriages, and deaths, \&c., are so many evidences of the increasing care of the Government and Legislature for objects of vast importance to the public welfare; and though some of the details of these measures have required; and still require, modification, to render them adequate to fulfil the intentions of those who framed them, and others, (the Puor-Law, for instance,) may, in their working, be franght with much that is evil, the principles on which they are founded are for the most part sound and equitable.

We rejoice in these manifestations on the part of the State authorities, of a desire for the inpıove. ment of the general condition of the comnunity ; yet though we hail them with satisfaction, it must be allowed that the merit of originating them mainly rests with private individuals, while the labour of forcing then on public attention has been severe, protracted, and wearisome.

To instance the last important provision of this nature which has received the sanction of the legislature-Lord Ashley's Acts for the improve. ment of the condition of the insane-it cannot but be admitted that the state for ages proved but a sorry step-mother to that afflicted and hapless portion of her sabjects. To the exalted humanity and courage of Pinel are we indebted for the first great step in the right direction, for the relief of these unhappy sufferers under the worst of all privations, and to the successive adoption and extension of his views by many honoured members of our own profession in this country, is the change in the public feeling in regard to the insane, as well as in the general principles and treatment to be adopted in reference to them, mainly to be attributed.

Most of the genuine reforms enforced in the I,unacy Acts have been anticipated by the energy and humanity of the medical proprietors and superintendents of publie and priveseiasyluas; and although the state of some few of thiem yet affords a glimpse of the retreating erils and abuses of a former systen, and calls for the exercise of a strict supervision on the part of the Government, the arrangements, whether for the reception and con. 